\title{
Morphological Changes along the shoreline of the arcuate Niger Delta from Parts of Delta State to Akwa Ibom State between 1986 and 2016
}

\author{
Gordon Tami Amangabara $^{1 *}$ \\ Obinna Michael Onyewuchi²
}

\begin{abstract}
This study analyzes the morphological changes occurring at the arcuate Niger Delta shoreline by identifying factors that contribute to erosion-induced shoreline changes and the rate of shoreline change from Forcados (Delta State) to Ibeno (Akwa Ibom State). Shoreline changes were compared from 1986 to 2016 as well as among western, central and eastern sections of the arcuate Niger Delta using Landsat satellite imagery within Geographic Information System (GIS) environment. In the assessment of the entire shoreline, accretion was 5,477.814Ha $(1.2 \%)$ in 1986 and $19181.53 \mathrm{Ha}(4.1 \%)$ in 2016. For erosion, it was 48,400.03 (10.3\%) in 1986 and $68398.84 \mathrm{Ha}(14.5 \%)$ in 2016. This indicates that accretion increased by $2.91 \%$ and erosion also increased by $4.25 \%$ in 30 years. The major accretion was detected within Brass (Bayelsa State), Bonny (River State), Andoni (River State) and Ibeno (Akwa Ibom State). Forcados South Point (Delta State), Sombreiro River mouths and eastern Obolo recorded the highest level of shoreline erosion. For land use/land cover (LULC), vegetation was $27.4 \%$ in 1986 but reduced to 22.9\% in 2016; a change I attributed to massive conversion of vegetative cover for anthropogenic activities in the area. The study concluded that major erosion cases are due to the changing climate and the velocity of flow of major estuaries into the ocean. The activities that contribute to the shoreline change aside the challenging natural factors are sand mining, hard and engineered structures on the shore and other commercial and social activities. The occurrences of shoreline erosion have contributed to the degradation of these coastal ecosystems, loss of human settlements and livelihood. It is therefore essential to implement precautionary measures to mitigate the risk of shoreline erosion within this sensitive zone
\end{abstract}

Keywords- Arcuate Niger Delta, coastline, shoreline, morphology, accretion, erosion

\footnotetext{
${ }^{1 *}$ Federal University Technology, Owerri, Department of Environmental Technology. *Corresponding author Email: gordon.amangabara@futo.edu.ng ${ }^{2}$ Federal University Technology, Owerri, Department of Environmental Technology
}

Ghana Journal of Geography Vol. 13 (1), 2021 pages 221-235

https://dx.doi.org/10.4314/gjg.v13i1.11 


\section{Introduction}

Nigeria occupies an area of 923,768 sq. km (356,669 sq. mi.), extending 1,127 km (700 mi.) East to West and 1,046 km (650 mi.) North to South with a total boundary length of 4,900 km (3,045 mi.), of which $853 \mathrm{~km}$ (530 mi.) is coastline (Usoro, 2010). The shoreline is the boundary intersection between coastal land and the surface of sea water body that keeps changing its shape and position continuously due to dynamic environmental condition usually associated or influenced by waves, tides, winds, storms, sea level changes and human activities. Braatz et al., (2006) in Eludoyin et al., (2011) observed that shoreline changes induced by coastal erosion and accretion are natural processes. These natural processes, as expressed by Braatz et al., (2006), are often accelerated by human activities e.g. dredging, physical development, mineral exploration, construction of ports and removal of vegetation, etc.

According to Brown et al., (2015), previous studies by the Nigerian Institute for Oceanography and Marine Research (NIOMR) stated that there has been an annual rate of erosion of about $20 \mathrm{~m}-35 \mathrm{~m}$ along the Bonny shoreline. This observation is not different from many other communities along the coast. According to Oyegun (2007), many communities along the coastline are low lying, barely above the high tide level heightening fears of coastal submergence. Awosika et al., (1992) in Arokoyu et al., (2014) has opined that in the event of slight sea level rise $70 \%$ of communities in the Nigeria's Niger Delta will be inundated. This is against the backdrop of densely populated settlement along the coast. The coast has long been an area of great importance, providing communities with a multitude of benefits such as food, clean water, jobs, recreation/tourism, natural harbours for commerce, trade, and transportation, and is critical for sustained fisheries. The attractiveness of the coast has resulted in disproportionately rapid expansion of economic activities, settlements, urban centers, and tourist resorts (Oyegun et al., 2016; Badru et al., 2017).

As strategic as the Niger Delta is, with its oil facilities and burgeoning population coupled with challenges of massive coastal erosion leading to disappearance of coastal settlements, there are only very few researches conducted at monitoring and determining shorelines changes. The bulk of research is in the Lagos Area, South West of Nigeria and a few at Bonny in Rivers State. The dearth of relevant research/data along other parts of the Nigerian coastline including the arcuate Niger Delta engendered this study.

Secondly, shoreline change monitoring is an issue of concern in coastal zone management because of the tendency of the ecosystems to support many populations (IOSR Journal of Environmental Science, Toxicology and Food Technology (Oyegun et al., 2016; Moran, 2003). 
This problem becomes worse whenever the countermeasures (i.e. hard or soft structural options) applied to control erosion or flooding is inappropriate (improperly designed, built, or maintained) and if the effects on adjacent shores are not carefully evaluated. Often, erosion is addressed locally at specific places or at regional or jurisdictional boundaries instead of at system boundaries that reflect natural processes. This anomaly is mostly attributable to insufficient knowledge of coastal processes (erosion, accretion and slope of coastal zones) and the protective function of coastal systems.

The aim of this study is to evaluate the morphological changes along the less frequently researched shorelines of Delta State, Bayelsa State and Rivers State.

\section{Materials And Method}

\section{Study Area}

The Niger Delta region is located in the central part of Southern Nigeria and bounded to the south by the Atlantic Ocean. This region has a coastline extending from the mouth of Benin River to the Imo River Estuary and spans about $500 \mathrm{~km}$. The study area extends along the Niger Delta coastline from $\left(5^{\circ} 2^{\prime} 47.10^{\prime \prime} \mathrm{E}\right.$ and $\left.5^{\circ} 46^{\prime} 57.06^{\prime \prime} \mathrm{N}\right)$ west of the Benin River in Edo State to $\left(7^{\circ} 41^{\prime} 26.00^{\prime \prime} \mathrm{E}\right.$ and $\left.4^{\circ} 29^{\prime} 56.37^{\prime \prime} \mathrm{N}\right)$ close to the Imo River in Akwa-Ibom State. The area bounds the Atlantic Ocean and four states in the South-South zone of Nigeria: Delta, Bayelsa, Rivers and Akwa-Ibom States. The region is also home to the largest contiguous Mangrove forest in Africa and third largest in the world, following Indonesia and Brazil (Nwilo, 2005). Ibe and Anitia (1983) identifies the swamps of the Niger delta as covering an area of about 9,000 sq. $\mathrm{km}$, most of which are heavy mangrove vegetation, tidal flat and are flood plains, lying between mean low and high tides. The Niger River bifurcates to form deltas through which the river drains into the Atlantic Ocean. The area encompasses several ecological zones including coastal barrier islands, mangroves, freshwater swamp forest and lowland rainforests. The beaches of the region receive sand from the coastal rivers and these are re-distributed by longshore currents (Ibe and Anitia, 1983).

The Niger Delta is the recipient of over $90 \%$ of all the waters from the Niger-Benue River systems and $100 \%$ of all water from streams rising in the Delta Region. The region is highly vulnerable to flood because of its flat terrain and resulting settlements along the river systems. The main rivers of focus in terms of sedimentary processes for this study are River Nun in Bayelsa State whose mouth is in Brass Island in Bayelsa State, River Sombreiro mouth 
(Degema, Rivers State) and Bonny River mouth (in Rivers State). The Major towns within the study area include: Twon-Brass, Degema, Bonny, Andoni, Opobo, Eastern Obolo and Ibeno.

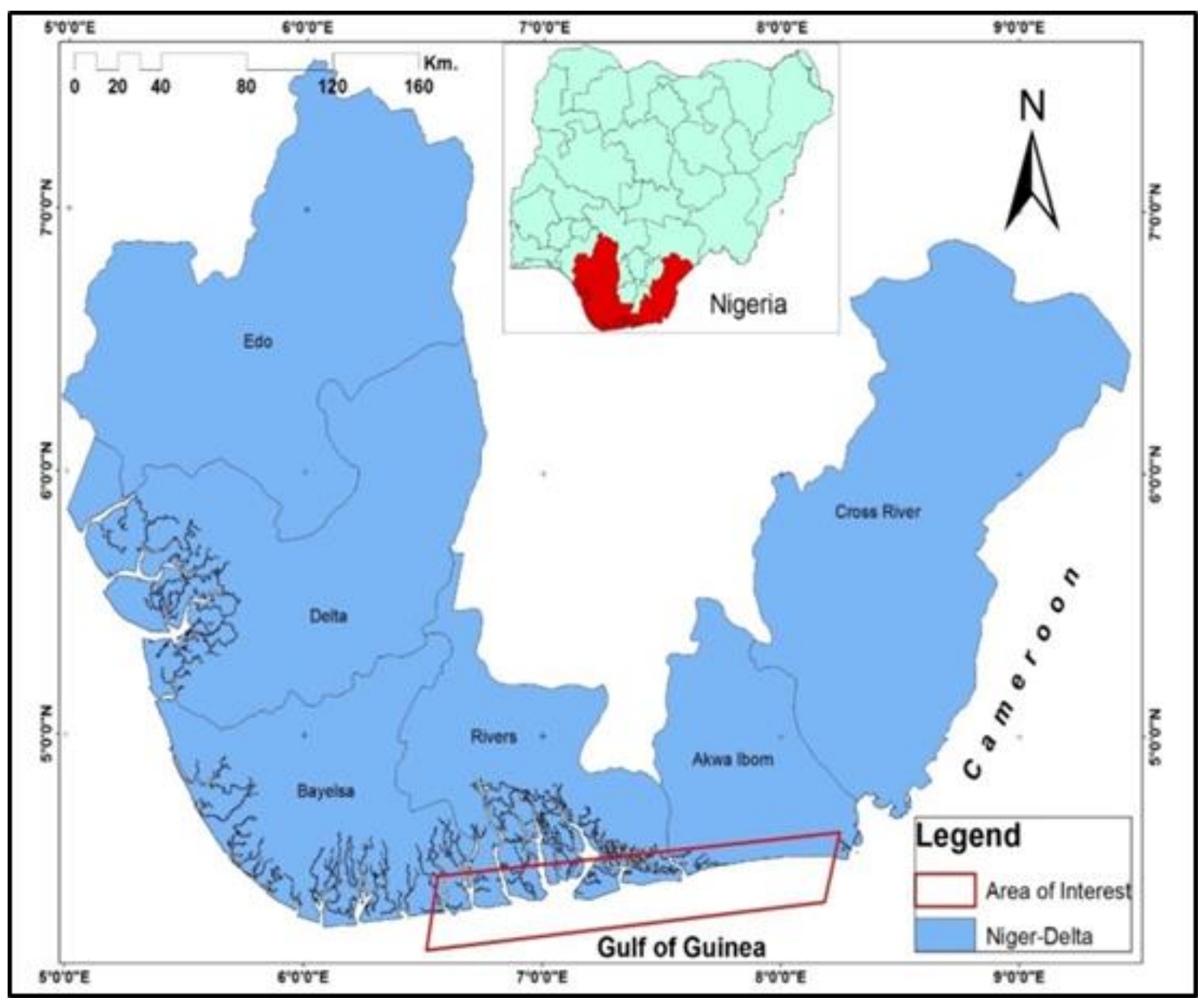

Figure 1: Map of Niger Delta

\section{Methods}

Changes in shoreline through processes of accretion and erosion can be analyzed in a geographic information system (GIS) by measuring differences in past and present shoreline locations. In recent times, the use of geospatial techniques have proven to be an extremely useful approach for the study of shoreline changes, due to synoptic and repetitive data coverage, high resolution, multispectral satellite imageries and its cost effectiveness in comparison to conventional techniques (Brown and Adekunle, 2015).

An integration of various secondary data provided through government sources and data bases from other organizations, the raw spatial data and satellite images used in the research were procured through the United States Geological Survey (USGS) and the GIS laboratory of the Department of Strategic 
Space Application, National Space Research and Development Agency (NASRDA), Abuja. Digital elevation dataset from Shuttle Radar Topographical Mission (SRTM) of 2010 were obtained from NASRDA. The imageries were acquired from online archive of United States Geological Survey, Earth Explorer data

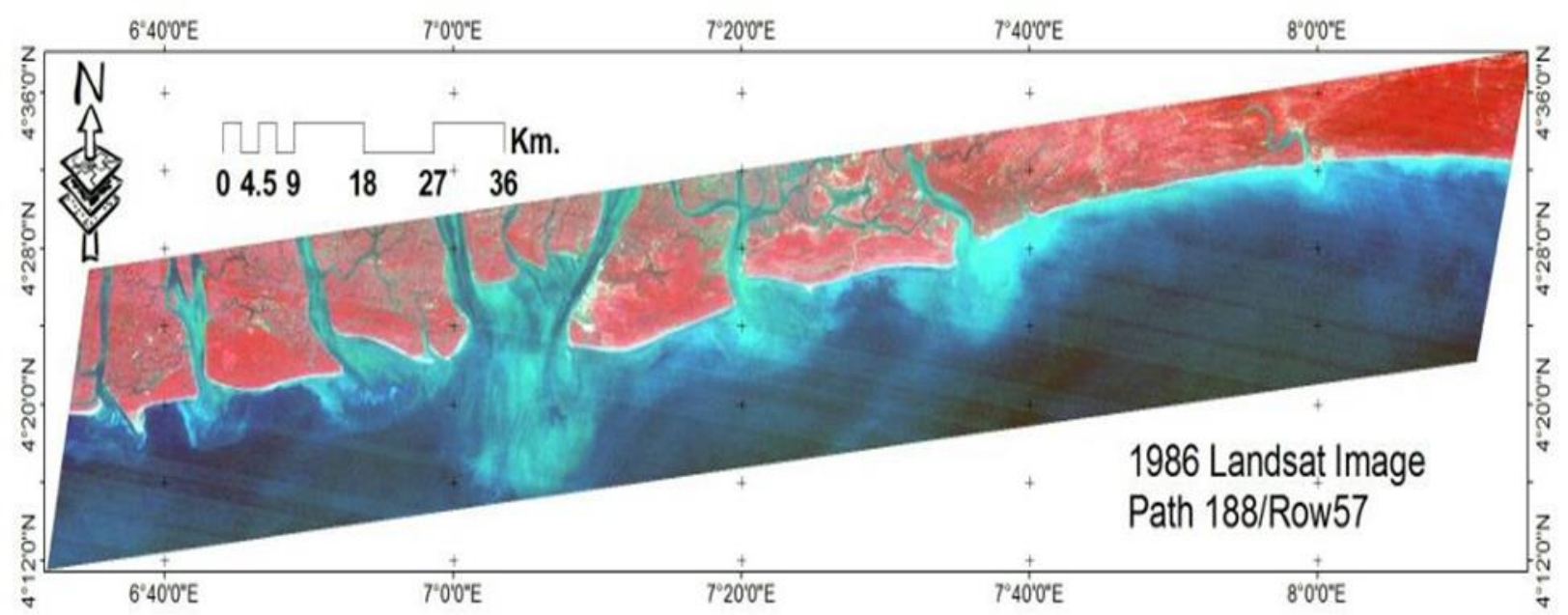

Figure 2: 1986 Landsat Image of the Study Area (Path 188/Row 57)

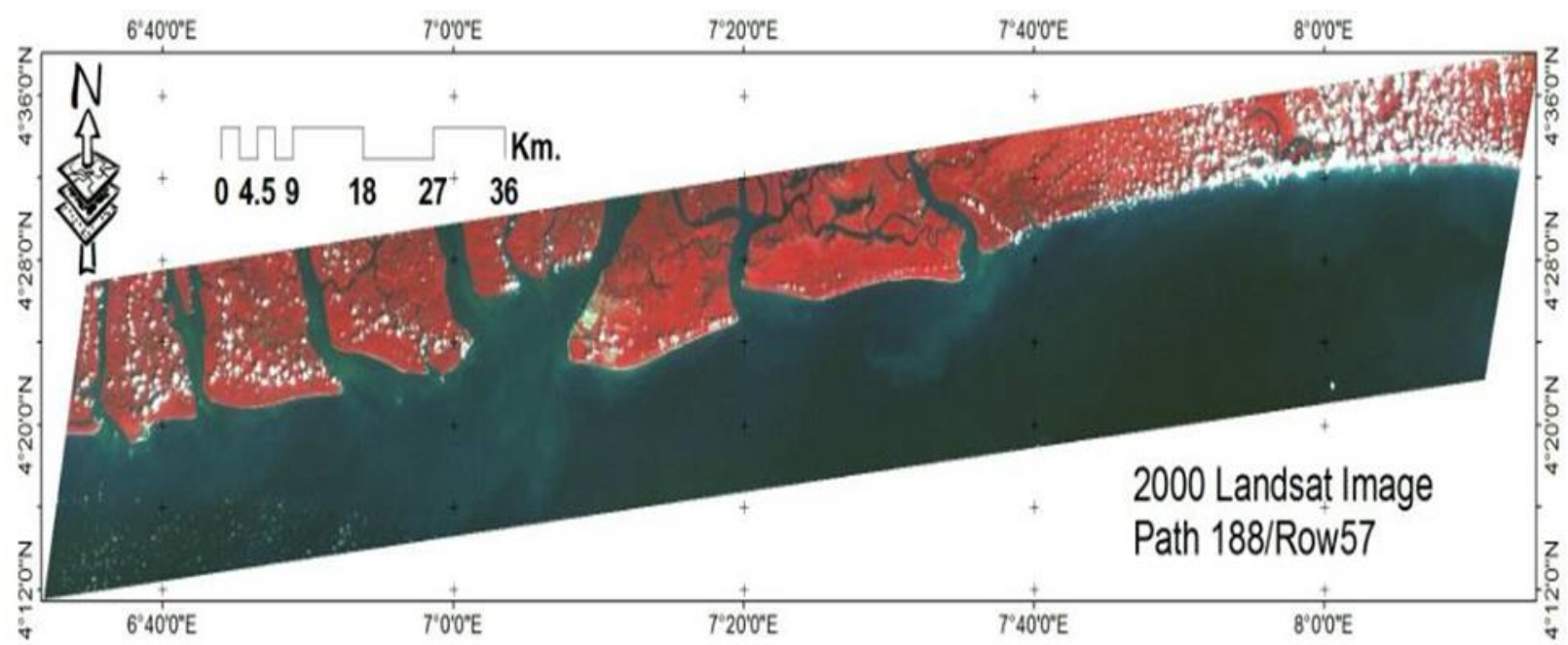

Figure 3: 2000 Landsat Image of the Study Area Path 188/Row 57 


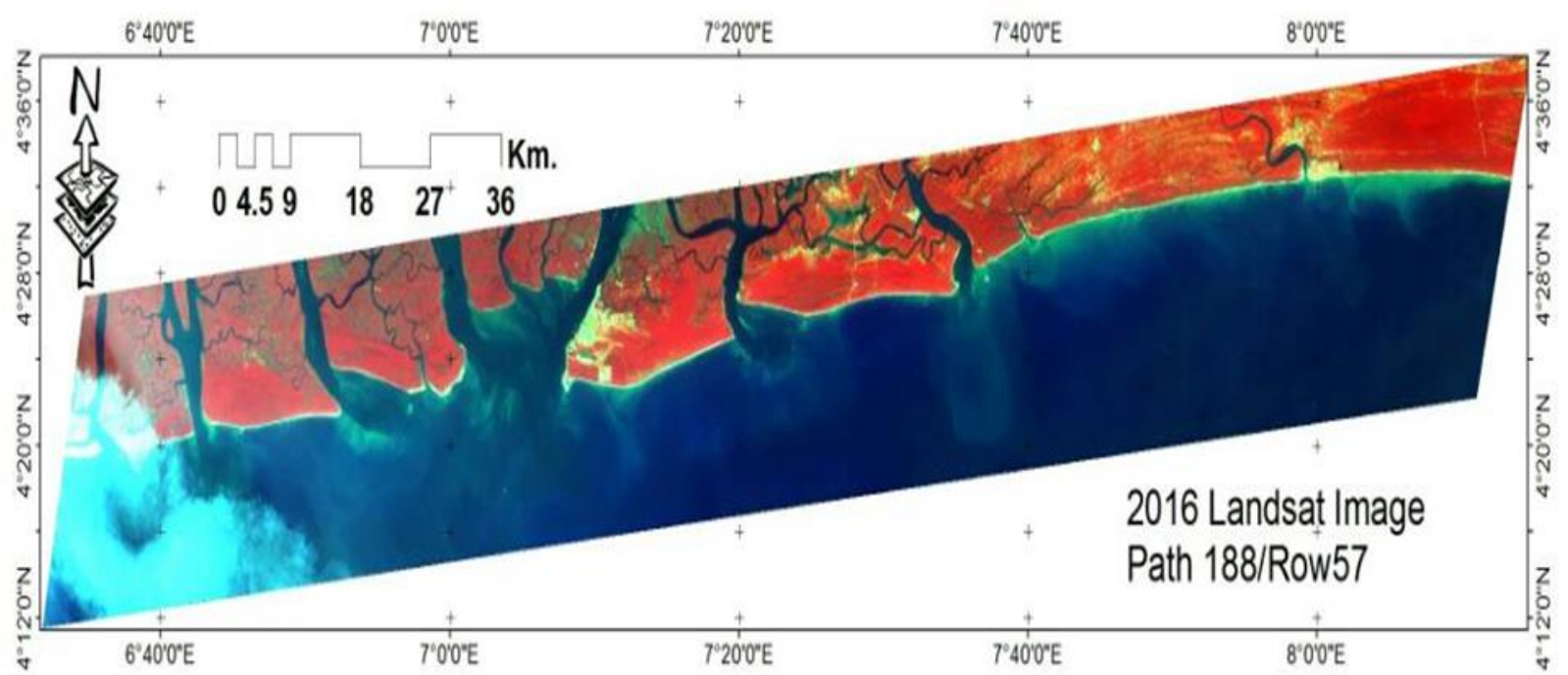

Figure 4: 2016 Landsat Image of the Study Area Path 188/Row 57

\section{Tools of Data Analyses, Processing and Procedure}

The general analyses were done with ArcGIS 10.0, Arc Map and Arc Catalogue. These were used for the vectorization of shapefiles, and digitization of the various features from the imageries, to generate the map of the study area. Arc Catalogue was used in creating geodatabase and shapefiles. The Landsat imageries were imported into ERDAS Imagine 2014 and the spatial, spectral and radiometric enhancement of the imageries was carried out. ERDAS Imagine was used to carry out colour composites. The image was clipped to concentrate on the area of interest showing the shorelines using the shapefile for study area map digitized from the ArcMap. ERDAS Imagine 2014 was used to classify the imageries using the Maximum Likelihood Classifier (MLC) to generate the land use and land cover (LULC) maps. The LULC maps were classified into vegetation cover, bare surface cover, water bodies and built-up surface cover.

The shoreline was digitized from the satellite data covering the years of the study period (1986 - 2016), with satellite data 2000 used as a baseline for the analysis: but it was not considered in generating the results of the study in terms of area of the LULC of the study area because of the cloud cover and irregularities with the pixel values, it was significantly unfit to generate the land use and cover map. The digitized shorelines were overlaid on the DEM map of the area to determine the contributions of the elevation of the area in the changes observed in the shorelines over the years 


\section{Results and Discussion}

\section{Land Cover Dynamics of the Shoreline}

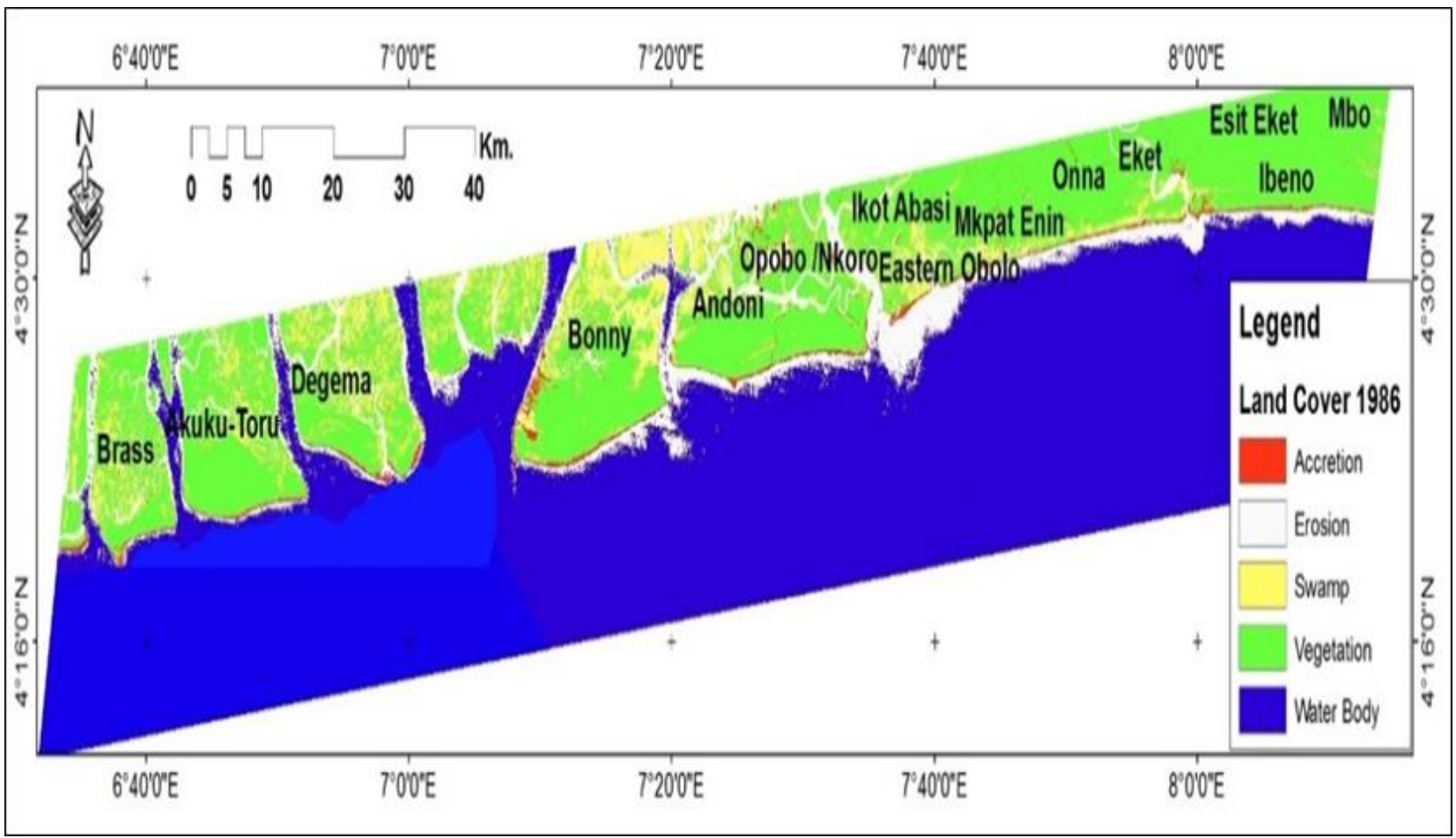

Figure 5: Land cover map of the study area in 1986

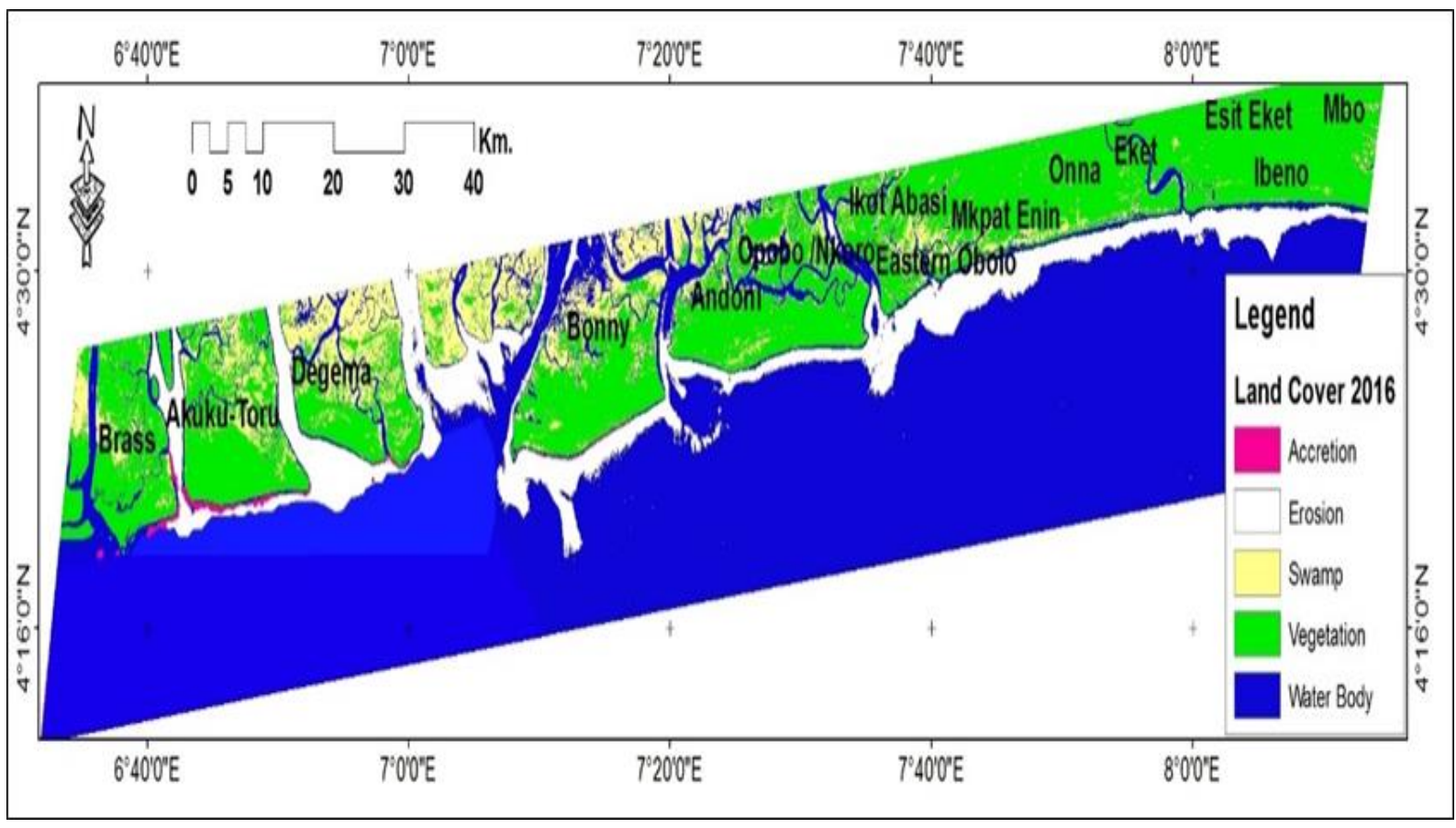

Figure 6: Land cover map of the study area in 2016 


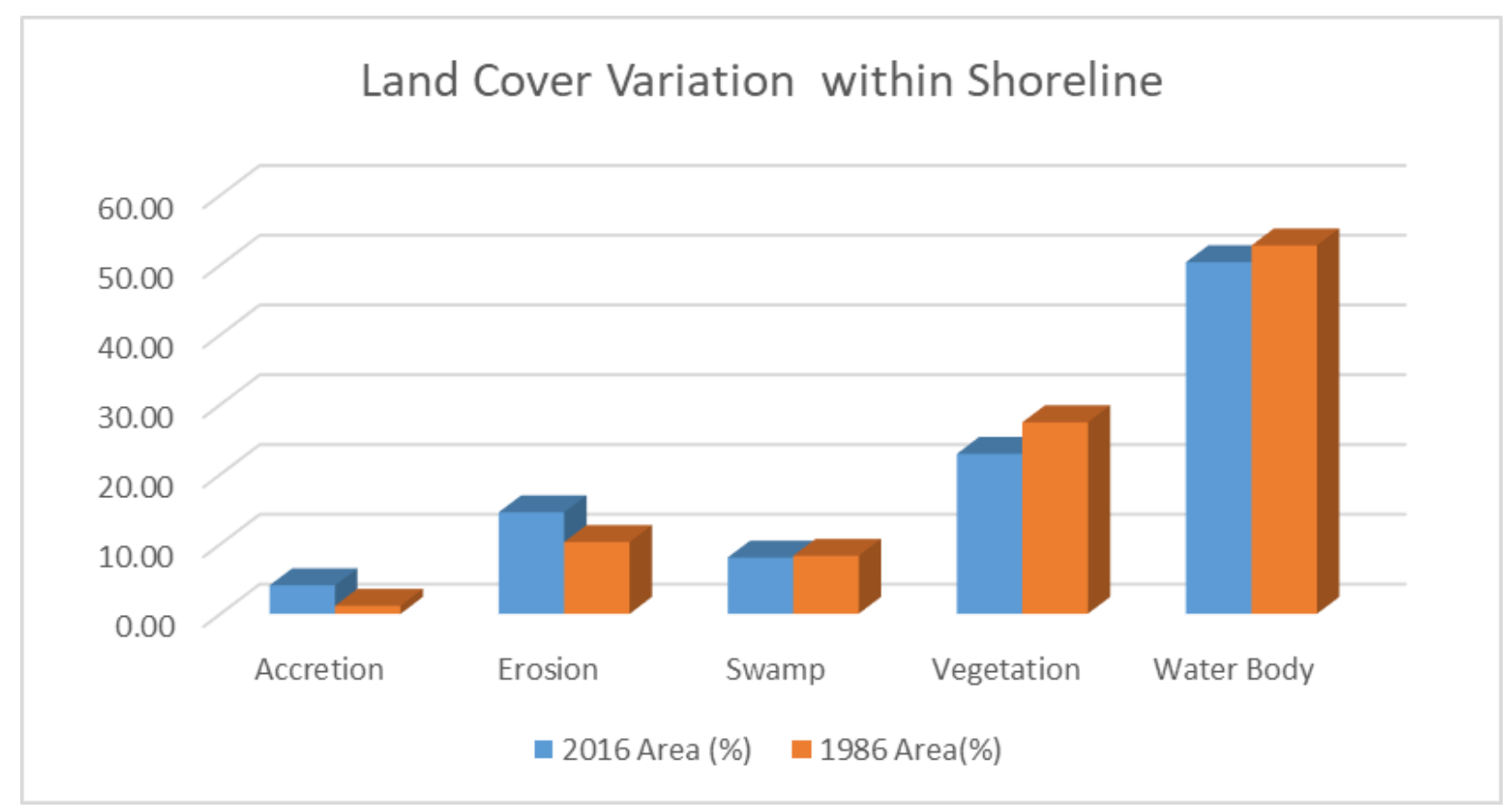

Figure 7: Comparison of land cover changes for target years.

Table 1 Land Cover Change within the shoreline.

\begin{tabular}{|c|c|c|c|c|c|c|}
\hline \multirow{2}{*}{$\begin{array}{l}\text { Land Cover } \\
\text { within } \\
\text { Shoreline }\end{array}$} & \multicolumn{2}{|l|}{ Area 2016} & \multicolumn{2}{|l|}{ Area 1986} & \multicolumn{2}{|c|}{2016 - 1986 Change } \\
\hline & Area Ha & $\%$ Area & Area Ha & $\%$ Area & Area Ha & $\%$ Area \\
\hline Accretion & $19,181.53$ & 4.1 & $5,477.81$ & 1.2 & $13,703.71$ & 2.9138 \\
\hline Erosion & $68,398.84$ & 14.5 & $48,400.03$ & 10.3 & $19,998.81$ & 4.2523 \\
\hline Swamp & $37,951.41$ & 8.1 & $39,115.69$ & 8.3 & $-1,164.28$ & -0.2476 \\
\hline Vegetation & $107,851.00$ & 22.9 & $129,084.10$ & 27.4 & $-21,233$ & -4.5147 \\
\hline Water Body & $236,927.00$ & 50.4 & $248,232.20$ & 52.8 & $-11,305.20$ & -2.4038 \\
\hline Total & $470,309.80$ & 100 & $470,309.80$ & 100 & & \\
\hline
\end{tabular}

(Generated from figs Figures 5 and 6 )

The 1986 Landsat image of the study area showed that water body constituted the largest proportion of land within the Shoreline area under study, with a value of $52.8 \%$, followed by vegetation, which accounts for $27.4 \%$. The total area affected by erosion was estimated from the Land use/Land cover (LULC) analysis to be 10.3\%, and swampy area was $8.3 \%$ in 1986 and with minor accretion of 1.2\%. (Figure 5) However, the LULC analysis of 2016 showed a decrease in the water body which now constitutes $50.4 \%$ of the total area cover within the shoreline area of interest, followed by vegetation accounting for $22.9 \%$. Comparing with 1986 imagery, it was observed that the area lost about $4.5 \%$ of the 1986 vegetation cover; this loss may be due to erosion, this assumption is corroborated by the area occupied by erosion in the 
LULC scheme of 2016 which shows that the area affected by erosion is $14.5 \%$, an increase of $4.2 \%$. Swamp area also decreased from $8.3 \%$ in 1986 to $8.1 \%$ in 2016 (Figure 6)

Spatial and Temporal Dynamics of the Shoreline.

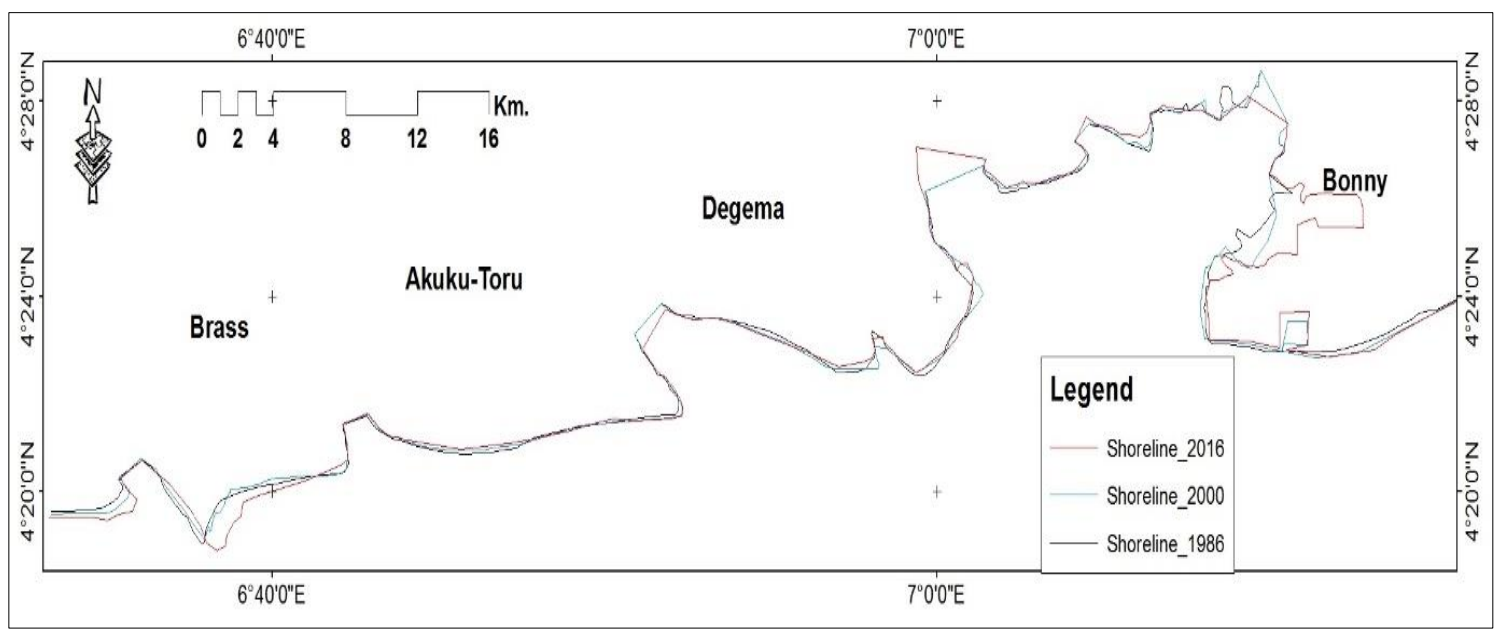

Figure 8: Shoreline variation from Brass to Bonny between 1986 and 2016.

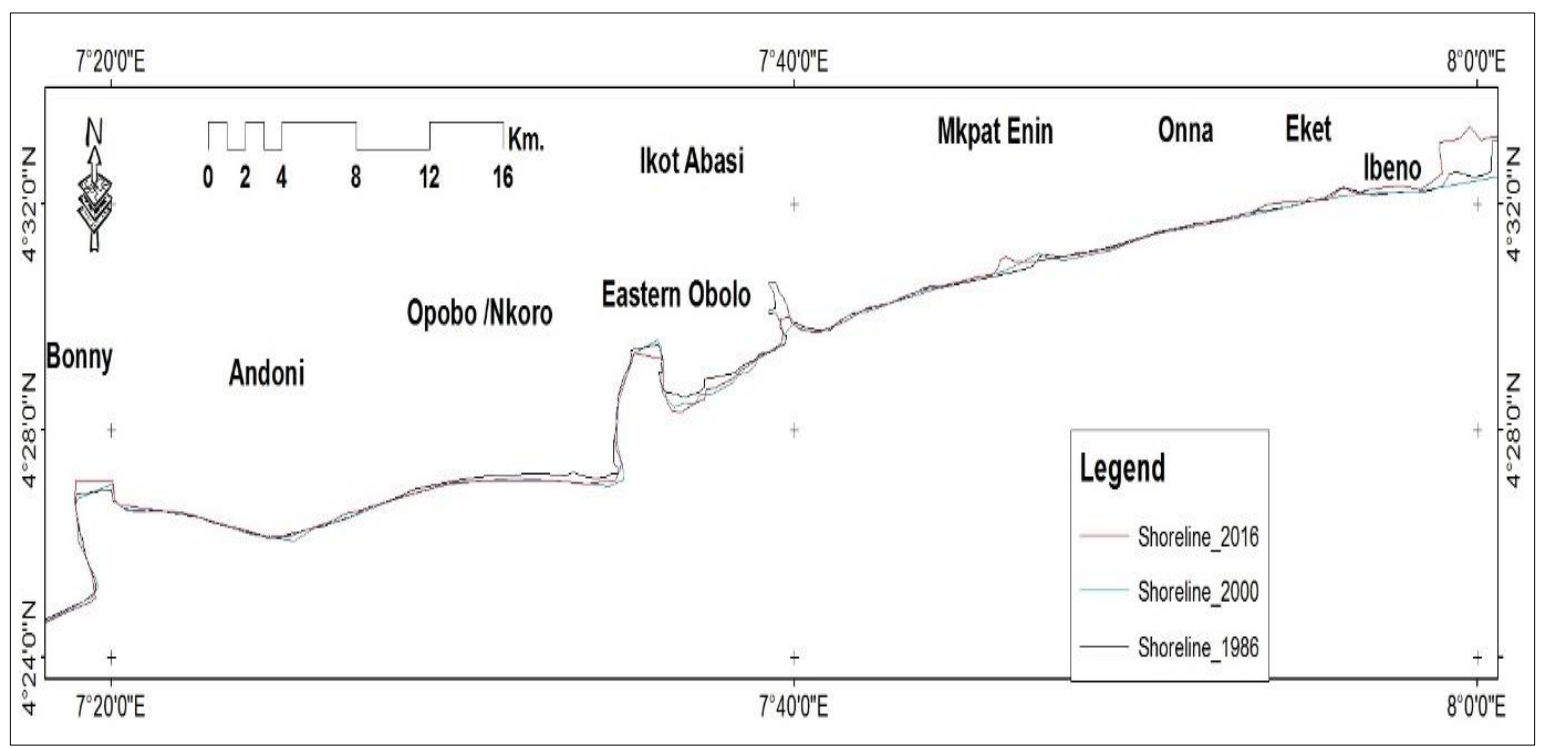

Figure 9: Shoreline variation from Bonny to Ibeno between 1986 and 2016

Figures 8 and 9 above, show obvious erosion within the Brass shoreline and between Degema and Bonny Shorelines. There were also noticeable accretion in the form of sand bars, spits and beaches along the sheltered zones of the shoreline in Brass, Degema, Andoni and Ibeno (Figure 9). 
Table 2: Accretion within the shoreline measured in Meters

\begin{tabular}{lll}
\hline \multirow{2}{*}{ Location } & \multicolumn{2}{c}{ Change in Shoreline } \\
& $1986-2000(\mathrm{M})$ & $2000-2016(\mathrm{M})$ \\
\hline Mouth of Brass River to Akuku-Toru & 344.13 & 515.31 \\
Between Degema to Bonny coastline & 119.45 & 259.78 \\
Between Bonny and Andoni coastline & 175.48 & 361.29 \\
Between Andoni and Opobo coastline & 191.15 & 134.81 \\
Eastern Obolo to Ibeno coastline & 107.96 & 297.5 \\
Ibeno River to about 4.7 km eastwards & 274.65 & $1,125.63$
\end{tabular}

(generated from Figure 8 and 9)

Table 2 showed that there was a considerable beach enrichment/accretion across the entire coastline however comparing tables 1 and 2, it would be noticed that there is net erosion along the entire coastline of about $1.34 \%$. Furthermore, it is also noticed that the bulk of accretion occurs in the sheltered coastline from Andoni to Ibeno which now compensates for the erosion that occurs at Brass River mouth, Degema (River Sombreiro mouth) and Bonny River mouth. These coastlines are opened to the sea and are severely exposed to the vagaries of weather (wind speed and rainfall) and oceanic influences (wave, current, and tide)

Generally, there are three major processes observed in the Gulf of Guinea that shape shorelines which includes:

i. Coastal dynamics and morphology (regular wave action, tides and winds,) - which depend on large-scale oceanic and climatic seasonal changes. Slow sea-level rise at a rate of $7 \mathrm{~cm}$ to $12 \mathrm{~cm}$ since the beginning of this century also favours wave attacks on the high foreshore and causes progressive retreat of gently sloping sandy shorelines (a few dozen centimetres per year)

ii. Sedimentary processes influenced by strong storms causing a rise in mean sea-level and thus favouring a direct attack on the highest part of the foreshore by up-rush and transfer of sediments down to the nearest part of the submarine beach and off the inner continental shelf. Forcados (Delta State) and Koluama I and II (Bayelsa State) are some typical examples.

iii. Fluvial processes by the river systems that feed the delta. Shoreline changes induced by erosion and accretion are natural processes that take place over a range of time scales. 
Wind, waves and currents are natural forces that easily move the unconsolidated sand and soils in the coastal area, resulting in rapid changes in the position of the shoreline. Excluding the impact of human activity, these processes are simply natural evolutionary phenomena. Human activities along the coast and offshores e.g. (land reclamation, port development, river damming and diversion, dredging and sand mining) in combination with natural forces often exacerbate coastal erosion in many places and jeopardize opportunities for coasts to fulfill their socio-economic and ecological roles in the long term at a reasonable societal cost.

The shoreline dynamic analysis show changes in the morphology of the arcuate Delta coastline in the last thirty (30) years. Along the entire coastline, coastal erosion was observed to be dominant over accretion or sediment deposition. This, when viewed from the background of previous work done by Ibe (1998), shows that erosion tendencies are still prevalent along the Niger Delta coast. The West coast of the study area records more accretion than erosion. A total area of 9.381 sq. $\mathrm{km}$. of changes was observed. Accretion accounts for $8.859 \mathrm{sq}$. km (94.44\%), while erosion accounts for 0.522 sq. $\mathrm{km}(5.56 \%)$. Annual rate of accretion and erosion are 0.521 sq. $\mathrm{km}$ and $0.031 \mathrm{sq}$. km respectively.

The major flash points of change observed along the coastline in this area (i.e. the Western part of the Study Area) are: Escravos River mouth, Escravos-Forcados rivers mouth axis, and Forcados (Ogulagha) Shoreline. Around the mouth of the Escravos River to the south-eastern part of the coastline, near Ogidigben, there were noticeable build-up of sand bars growing seawards but after that section, at South Point Forcados (Ogulagha) erosion became severe, the River Forcados seem to push out the inter-tidal systems outward, this action is enhanced by oil exploration activities which has resulted in the removal of bank materials to serve as landing jetties, tank farms etc. 


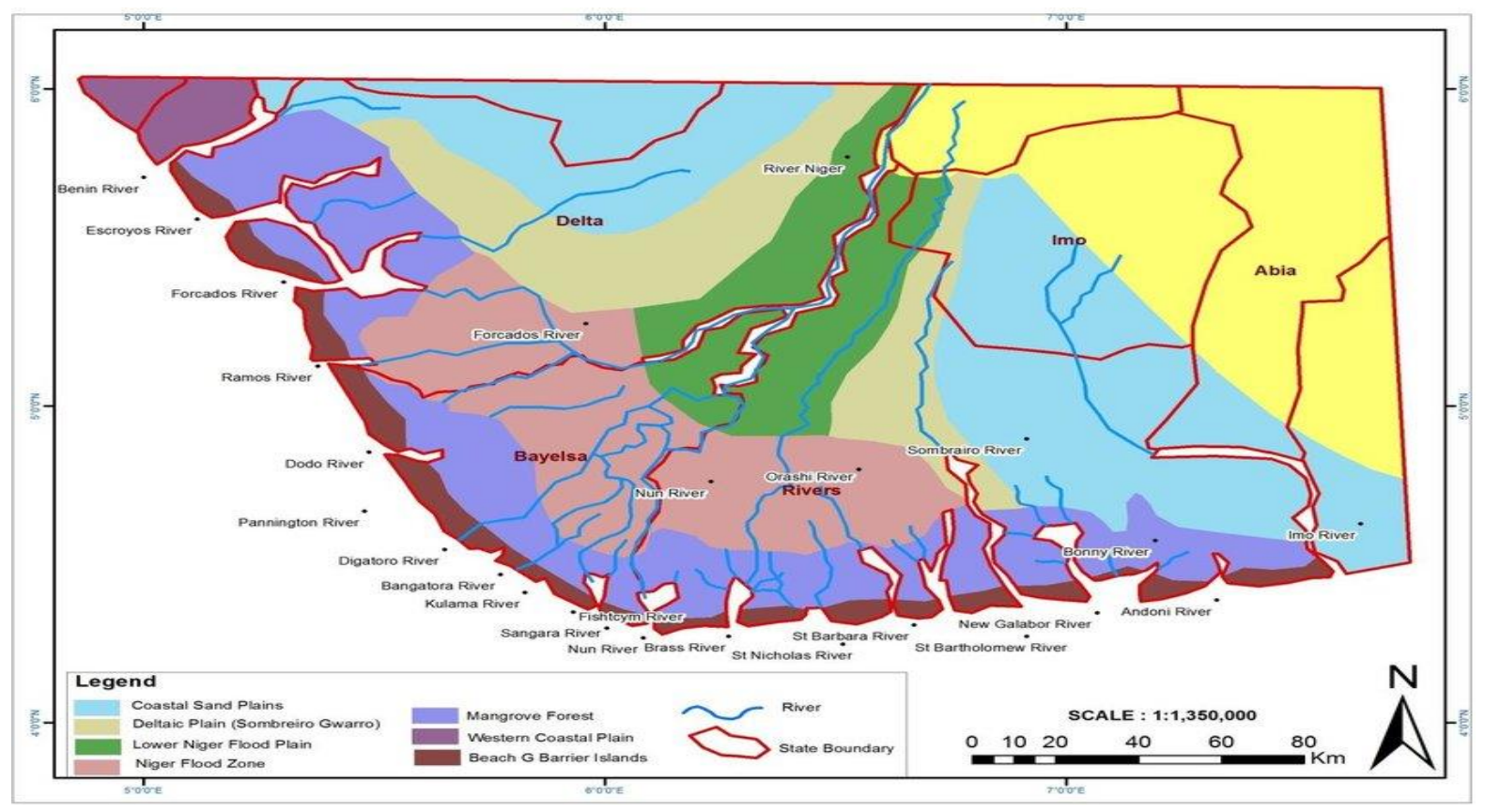

Figure 10: Map showing the various River Mouth as they empty into the Gulf of Guinea

The coastline stretching from Brass River (River Nun) estuary (Bayelsa State) to Sombreiro River estuary in Degema (Rivers State) also recorded massive erosion and accretion in some hot spot. About $16 \%$ of the coastline change in this section occurred around the Brass River mouth down to Dodo River mouth moving eastwards along the coastline, between Dodo River and Santa Barbara river mouths. The coastal erosion on the shoreline of Twon-Brass (i.e. the western portion facing Igbabele) is increasing yearly with an average of 59.52322 meters of land mass lost to coastal erosion and a total area of $59.52322 \mathrm{~m}$ by $8000 \mathrm{~m}$ that is $476160 \mathrm{~m}^{2}$ land mass. Some of the damages caused by the erosion along this stretch which happens to be the Community foreshore include loss of land, loss of structures such as buildings, loss of farmland, loss of biodiversity and salinization of inland water. Meanwhile accretion occurs on the southeastern part forming beaches due to the longitudinal flow of the Guinea current.

The segment that starts from the Sombreiro River estuary (covering the eastern part of the mouth of the Santa Barbara River to about $3.2 \mathrm{~km}$ east of Imo River mouth) in Rivers State, extending to the Qua-Ibo River estuary in Akwa Ibom State can be described as the eastern section of the arcuate Niger Delta. Between 1986 and 2000 the shoreline change was $119.45 \mathrm{~m}$ between Degema and Bonny, 175.48m between Bonny and Andoni, 191.15m between Andoni and Opobo and about 390m between Opobo and Ibeno River mouth. For 2000 to 2016, the entire mentioned coastline increased in the changes except Andoni - Opobo that showed a decline in erosion, the land reclamation project at Opobo by the Rivers State Government 
between 2008 and 2014 may have contributed significantly to this. The area that was most susceptible to erosion is between Sombreiro and New Calabar River estuaries.

\section{Conclusion}

The Niger delta region of Nigeria is bounded to the south by the Atlantic Ocean. This region, which is rich in biodiversity and organic mineral resources, has a coastline extending from the mouth of the Benin River in the west to the mouth of Imo River in the east and this spans about $500 \mathrm{~km}$. Since the early $1900 \mathrm{~s}$, this coastal region has been extensively used for navigation and port activities. The discovery of crude oil in commercial quantity in the region four decades ago further exacerbated developmental activities around the coast. The coastal activities include: oil and gas exploration and exploitation; upstream damming of the Niger River; construction of ports and the continuous dredging of major river estuaries for navigation inland. These activities as well as the cyclical actions of ocean currents and waves have largely contributed to dynamic changes in the geomorphology, vegetation cover, sediment deposition and erosion along the coastline. The resultant effect of the changes in sediment budget has been constant flooding of coastal communities with monumental socio-economic impacts such as loss of lives and properties.

Along the entire coastline, erosion phenomenon was observed to be dominant over accretion or sediment deposition. The total area of observed changes along the coastline over the 30 -year epoch showed that while erosion and accretion occurs to influence the changes of the shoreline, erosion contributed more by $1.33 \%$. The study concluded that major erosion cases were observed along Brass, Degema, and Eastern Obolo in 2016 due to the changing climate and the velocity of flow of major estuaries into the ocean and mainly accelerated by significant reduction of vegetative cover at the upstream for developmental and commercial activities. While major accretion was detected within Brass, Bonny, Andoni and Ibeno Shoreline within the period of 1986 - 2000. These areas were observed to be used for operation like oil wells, recreation activities and commercial/residential activities in the case of Opobo town. 


\section{References}

Arokoyu, S.B. and Ogoro, M. (2014). Vulnerability of Bonny Coastal Communities to Sea Level Changes Quest Journals Journal of Research in Environmental and Earth Sciences Volume 1. Issue 3 (2014) pp: $32-43$ ISSN(Online) : 2348-2532 ww.questjournals.org $34 \mathrm{p}$

Awosika, L. F., French, G. T., Nicholas, R. J., and Ibe C. E. (1992). The Impact of Sea Level Rise on the coast of Nigeria.

Badru,G., Odunuga, S., Omojola, A. and Oladipo, E. (2017). Shoreline Change Analysis in Parts of the Barrier-Lagoon and Mud Sections of Nigeria Coast. Journal of Extreme Events. Vol.04, No. 04, 1850004

Braatz S., Fortuna, S., Broadhead, J., and Leslie, R. (2006).Coastal protection in the aftermath of the Indian Ocean Tsunami: What role for forests and trees? Proceedings of the Regional Technical Workshop, Khao Lak, Thailand, 28- 31 August.

Brown, J. and Adekunle, I. A. (2015). Assessment of Shoreline Dynamics at Bonny Island, Nigeria using Geospatial Techniques. International Journal of Scientific Research in Science and Technology (www.ijsrst.com)

Eludoyin, O.S., Oduore, T. and Obafemi, A. A. (2012). Spatio-Temporal Analysis of Shoreline Changes in Bonny Island, Nigeria. Ethiopian Journal of Environmental Studies and Management EJESM Vol. 5 No. 22012

Ibe, A. C., and Anitia, E. E. (1983). Preliminary Assessment of impact of erosion long the Nigerian shoreline; Nigerian Institute for Oceanography and Marine Research; technical paper No.3

Moran, C.A.A. (2003). Spatio-temporal analysis of Texas shoreline changes using GIS technique 24.30

Nwilo, C. (2005). A View from the Developing World. In Adegoke, J.O., Fagbeja, M., James, G., Agbaje, G. and Ologunorisa, T.E. (2010): An Assessment of Recent Changes in the Niger Delta Coastline Using Satellite Imagery Journal of Sustainable Development, 3(4), 277-296.

Oyegun, C. U. (2007). Climate Change and Nigeria Coastal Resources. Nigeria: UPPL.

Oyegun, C. U., Lawal, O. and Ogoro, M. (2016). The Dynamic Nature of Niger Delta Shoreline. IOSR Journal of Environmental Science, Toxicology and Food Technology (IOSR- JESTFT) e-ISSN: 2319-2402,p- ISSN: 2319-2399.Volume 10, Issue 5 Ver. I, PP 50-58 www.iosrjournals.org

Usoro, E. (2010) Nigeria. In: Bird E.C.F. (eds) Encyclopedia of the World's Coastal Landforms. Springer, Dordrecht. https://doi.org/10.1007/978-1-4020-8639-7_171 